\title{
EXPORTING AND PRODUCTIVITY: EVIDENCE FOR EGYPT AND MOROCCO
}

\author{
INMACULADA MARTÍNEZ-ZARZOSO ${ }^{1}$ \\ Department of Economics and Institute of International Economics, Universitat Jaume I, \\ Castellón (Spain) \\ Department of Economics and Center for Statistics, Georg-August Universitaet Goettingen \\ (Germany) \\ E-mail: martinei@eco.uji.es
}

Forthcoming in Middle East Development Journal (2020)

\footnotetext{
* Corresponding address: Department of Economics, Georg-August Universitaet Goettingen, Platz der Goettinger Sieben 3, Goettingen (Germany). E-mail: martinei@eco.uji.es. The author acknowledges the support and collaboration of Project ECO2010-15863. She also would like to thank the participants in the 14th Workshop in International Economics held in Goettingen for their helpful comments and suggestions.
} 


\title{
Exporting and Productivity: Evidence for Egypt and Morocco
}

\begin{abstract}
This paper investigates the link between exporting and importing activities and firm performance using a rich dataset on Egyptian and Moroccan firms. We test the export premium, self-selection and learning-by-exporting hypotheses using a number of firm characteristics. Our analysis also includes importing activities as a source of learning and considers their effects on productivity changes. A differences-in-differences matching estimator is used to address the endogeneity bias of target variables. The main results for Egyptian firms echo those reported for other countries using firm-level data, namely exporters are larger and more productive than non-exporters. In contrast, Moroccan exporters and non-exporters are strikingly similar. More specifically, no evidence is found of pre or post-entry differences in labour productivity for Moroccan firms.
\end{abstract}

JEL classification: F10, F35

Keywords: firms, new-new trade theory, productivity, exporting, panel data, Egypt, Morocco

\section{Introduction}

Both old and new trade theories typically assume a representative firm, at least within each industry. This assumption is inconsistent with the substantial variation in productivity, capital intensity and skill intensity observed across firms and within industries. The interaction of firm characteristics and the export orientation of a firm provide a channel for international trade to influence aggregate productivity (Bernard et al., 2007 and 2011). Recent empirical evidence indicates that exporting firms are different from non-exporting firms. In particular, most firms in a given industry are non-exporters and exporters are in general more productive, employ more workers and earn higher revenues (Greenaway et al. 2007).

Recently available micro-level data make it possible to examine a number of new dimensions of international trade, including the concentration of exports, the infrequency of export activity, the range of products that firms export and the variety of destinations to which firms' exports are shipped. And not only this, the data permit the evaluation of the effects of trade 
liberalization on exporting and importing activities at firm level and also on the average productivity of firms.

The seminal paper by Melitz (2003) introduces firm heterogeneity in terms of different productivity levels across firms, explains the differences between exporters and non-exporters and adds increasing average productivity as a new source of welfare gains derived from trade. The Melitz model can explain some of the reported empirical facts, namely that exporters are different and self-select themselves into export markets. According to this model, the effects of trade on productivity and firm dynamics are threefold. Firstly, the least productive firms are forced to exit, whereas the most productive firms earn higher profits and gain market shares. Secondly, most firms earn less profits and thirdly, welfare rises not only due to an increase in available varieties but also to reallocation, which induces average productivity gains.

The main aims of this paper are to analyze the new dimensions of international trade using firm-level data collected by the World Bank for two South Mediterranean countries, namely Morocco and Egypt. In particular, we aim to test the export premium, self-selection and learning-by-exporting hypotheses using a number of firm characteristics and a differences-indifferences matching approach. We also explore to what extent firms have been involved in exporting activities and whether a change in average productivity and the number of firms in each industry can be observed over time. The focus on these two countries is mainly due to panel data availability and to their economic importance in the region.

The main source for our data is the World Bank Enterprise Survey (WBES) dataset, which gathers information for a representative number of firms concerning their production process, innovative capacity and internationalization, among other aspects. Two panels of manufacturing firms are available for Morocco and Egypt for the years 2004 and 2007. To the 
best of our knowledge, these data have not been used yet to study the relationship between trade and productivity.

There is indeed no published firm-level evidence for Egypt and only some limited evidence at micro-level for Moroccan firms in the 1990s using data from national surveys (e.g. Augier et al., 2010; Clerides et al., 1998 and Fafchamps et al., 2008). The findings concerning the "selection-into-exporting" hypothesis using Moroccan firm-level data are mixed. Augier et al. (2010) report that exporters do not perform better on average than non-exporters, while Clerides et al (1998) find the opposite. As regards the "learning-by-doing" hypothesis, Augier et al. (2010) and Fafchamps et al. (2008) find weak evidence supporting it.

This paper uses a more detailed dataset that covers a representative number of firms and more recent years. It also provides the first empirical evidence on firm heterogeneity in international trade for Egyptian firms. By controlling for unobserved heterogeneity among firms and correcting for endogeneity bias, the estimations should allow us to investigate the direction of causality and determine whether more productive firms become exporters, whether exporting firms learn by exporting and become more productive afterwards or both. We also aim to extract some policy recommendations for Mediterranean countries. In particular, we expect to shed light on the relationship between exporting activity and average productivity over time and through this on the possible poverty impact of trade liberalization. If trade and trade policies could be identified as factors influencing productivity, the next question will be to choose the appropriate instruments to enhance trade and subsequently productivity at the firm-level.

The rest of the paper is structured as follows. Section 2 summarizes the relevant literature related to Egypt and Morocco. Section 3 presents the empirical strategy, describes the data and shows the main findings and Section 4 concludes. 


\section{Literature review}

The literature that investigates the relationship between trade and productivity focuses on three main hypotheses: the export premium, the selection hypothesis and the learning-byexporting hypothesis. The export premium hypothesis mainly argues that exporters perform better in terms of sales, productivity and number of workers than non exporters, but does not establish the direction of causality, whereas the selection hypothesis states this is due to firms that enter the export market already being more productive before starting to export. In contrast, the learning-by-doing hypothesis argues that firms learn by exporting and therefore become more productive during the process of exporting (e.g. Bernard et al., 2007, Greenaway et al. 2007).

As regards the general results obtained for developed and developing countries, it is worth mentioning two recent surveys. On the one hand, Wagner (2007) shows that a majority of studies find that firms that export are on average more productive than firms that do not export and that there is evidence of 'self-selection' in the exporting process. However, the evidence on the 'learning effect' is rather mixed, indicating that exporting does not always improve productivity. On the other hand, Martins and Yang (2009) conduct a meta-analysis of more than 30 published papers that study the causal relationship between exporting and firm productivity. They find that there is no evidence of publication bias in the literature about the effects of exporting on firm performance. According to their findings the impact of exporting on productivity is higher for developing than for developed countries, and the export effect is likely to be influenced by different outcome variables used to measure firm performance and different estimation methods.

Despite the increasing number of studies that explore the relationship between trade and productivity using micro data, only a few of them focus on firms located in Northern Africa. In particular, Clerides et al. (1998) uses firm data for Colombia, Mexico and Morocco for the 
1980s and early 1990s, finding evidence of self-selection but no evidence of differences in productivity growth between exporters and non-exporters (learning by exporting). By contrast, Fafchamps et al. (2007) uses similar data for Morocco, finding evidence of some learning-by-exporting linked to the creation of new products, but not linked to the general exporting experience of the firm. Surprisingly - and contrary to previous research - Augier et al (2010) does find evidence of lower aggregated productivity after trade liberalization, also using firm data for Morocco for the period 1993-2002. This is partially explained by the entry of less productive firms in export markets, which however tend to have higher levels of productivity growth.

As regards studies covering the Middle East and North Africa (MENA) Region, it is worth mentioning two recent studies. The first, Sekkat (2010), assesses the role of within-firm effects, reallocation and turnover in changes in productivity in the MENA region. The author finds that the major source of productivity change over time is an increase in productivity within surviving firms, while other factors such as turnover and between-firm effects, are less important than in other countries. As a consequence, it could be that high entry and exit barriers play an important role in the MENA region, where existing regulations to create a business may prevent entry. In the second study, Atiyas (2011) summarizes the research that uses firm-level data in MENA countries to analyze productivity and its relationship to trade, trade policy and financial constraints. He also identifies the main research questions that could be addressed in the near future using the firm-level data available. He emphasizes the fact that the recently available firm-level data covering MENA countries provided by the World Bank Enterprise Survey (WBES) have not yet been utilized by researchers to investigate the relationship between trade and productivity.

Finally, in regard to the effect of trade liberalization on trade and productivity, Tybout (2000) surveys a large number of studies of trade liberalization reforms in developing countries and finds that trade liberalization is associated to higher average productivity and that within- 
industry reallocations of resources typically dominate cross-industry reallocations of resources. In the same line, Bartelsman and Doms (2000), using data for a cross-section of countries over time, find that labour productivity growth is to a great extent driven by withinfirm changes in productivity. This is also the outcome obtained by Pavcnik (2002) for Chilean firms, which rely on productivity variation across sectors.

\section{Empirical Strategy}

\subsection{Methodology}

The methodology applied in this paper to analyze the relationship between exports and productivity is the differences-in-differences matching estimator proposed by Heckman et al. (1997). Starting with Wagner (2002), this methodology has been applied in recent studies to generate matched firms that are comparable and to obtain unbiased estimates of target coefficients (Greenaway and Kneller, 2004; Greenaway et al., 2005; Damijan and Kostevc, 2007; De Loecker, 2007; Yang and Mallick, 2010; are some examples).

We will examine three main hypotheses: first the existence of an export premium for exporters (exporters are expected to have higher average labour productivity than non exporters and to be larger in both size and sales), second, the selection-into-exporting hypothesis (exporters self-select themselves into exporting and are more productive than non exporters before they start to export) and third, the learning-by-doing hypothesis (starting to export early increases productivity).

In order to properly assess the causality from export behaviour to firm performance or the other way round, the existence of a sample selection problem should be taken into account. In particular, what is needed is to consider the fact that the group of exporter firms is not randomly selected from the entire population. For instance, in order to determine the impact of exporting on productivity (learning-by-doing), a simple comparison between the 
characteristics of exporters and non-exporters cannot reveal the direction of causality. Indeed, the effect we wish to identify is the average effect of export activity on exporters in regard to firm performance. This effect is known as the average treatment effect on the treated (ATT) (Wooldridge, 2002). In the analysis, we compare firms entering an export market (treated firms) in a given year to firms not entering the export market (untreated firms) in the same year.

Suppose $D i$ is a variable that takes a value of 1 if a firm is an exporter (that is, the firm is exposed to treatment) and 0 if it is a non exporter. Each firm has two potential outcomes: $Y i$ $(D i=1)$, if it is exposed to treatment, $Y i(D i=0)$ if is not exposed. However, in nonexperimental studies, only one of the two outcomes is observed for the same firm. Hence, only $E(Y i(0) \mid D i=0)$ can be computed directly, whereas $E(Y i(0) \mid D i=1)$ cannot. Different econometric techniques have been developed in non experimental studies to overcome the bias generated when computing ATT. A first estimation technique is the Differences-inDifferences (DID) estimator. DID compares the differences in outcomes before and after a treatment for the treated group with the same differences for the untreated group, relying on the assumption that, without the treatment, the outcomes for both groups would have followed parallel paths.

A second estimation method employed in non-experimental studies to control for ATT bias is the propensity score matching (PSM) technique (Rosenbaum and Rubin, 1983). The first aim of the matching estimator is to reduce the bias that is due to non-overlapping support of $\mathrm{X}$ (where X stands for firms' characteristics, usually compared firms are already different in the pre-treatment period) and the second is to reduce the bias that is due to miss-weighting on the common support of X (Heckman et al., 1997). In fact, even in the common support, the distribution of the treated and of the untreated could be different. The traditional econometric selection bias that stems from "selection on unobservables" is supposed to be absent. It is 
worth noting that the matching method is based on the assumption of conditional independence (CIA). This assumption states that the potential outcome in the non-treatment scenario is independent of the treatment status conditional on observables $(\mathrm{X})$. A problem arises when the dimension of $\mathrm{X}$ is high; in this case the computation of ATT becomes unfeasible. In order to solve this problem, the treatment status can instead be conditioned on $P(X)=\operatorname{Pr}(D=1 \mid X)$, as shown by Rosenbaum and Rubin (1983), where $\mathrm{P}(\mathrm{X})$ is the propensity score. In this way, the so-called "curse of dimensionality" can be solved and ATT identified. Both DID and PMS can be combined when the data available have a panel structure to increase the robustness of the estimated effects (Heckman et al. 1997). This is the strategy we are going to follow in this paper. First we will estimate propensity scores using all factors that affect both the selection into exporting and the outcomes of analysis (productivity and size) as independent variables. The assumption of conditional independence will only hold if a suitable counterfactual can be used. As exogenous firm characteristics, lagged productivity, sales, employment, capital endowment, skill intensity and sector and geographical characteristics are used. In our approach, non-exporters are matched to first-time exporters according to their propensity scores using the nearest neighbour with the calliper method. We apply the usual marginal production function estimation, written in difference-in-differences terms to these matched pairs. First, the sample of matched firms and the corresponding controls has been selected for each of the two years available in the panel and then these treated and matched control firms for each year are pooled together. Although we report the results obtained by using the single nearest neighbor matching with calliper, comparable treatment effects were obtained with alternative matching techniques, namely radius matching and kernel matching.

In order to estimate the export premium (difference in productivity between exporters and non-exporters), we specify the following equation, 


$$
\beta_{A T T}=E\left[y_{i t} \mid \rho, D X=1\right]-E\left[y_{i t} \mid \rho, D X=0\right]
$$

where yit denotes labour productivity (alternatively total factor productivity, number of workers or total sales) of firm $\mathrm{i}$ in year $t$ and $\beta_{A T T}$ denotes average treatment effect (difference in productivity between matched exporters and non-exporters) and DX is a dummy that takes a value of 1 if a firm is exporting in a given year. $\rho$ denotes the propensity score which is estimated using a probit equation in which exporting status depends on firm characteristics, including capital, employment, firm age, regional dummies, sector dummies and year dummies. These variables are listed and described in Table A1 in the Appendix. The balancing propensities have always been satisfied, as well as the common support (see Figures A1 and A2 in the Appendix).

Next, in order to evaluate the self-selection hypothesis - more productive firms become exporters - the same technique is used and the following equation is estimated,

$$
\beta_{A T T}=E\left\lfloor y_{i, t-p} \mid \rho, D X=1\right\rfloor-E\left\lfloor y_{i, t-p} \mid \rho, D X=0\right\rfloor
$$

where $y_{i t-p}$ denotes labour productivity (alternatively total factor productivity, number of workers or total sales) of firm $i$ in year $t-p$ and with $0<\mathrm{p}<3$. It compares the performance of entrants vis-a-vis non exporters in the years before entry (Bernard and Jensen, 1999). In this case lagged values of firm characteristics are used to estimate the propensity score.

Finally, the learning-by-exporting hypothesis is evaluated using the following equation,

$$
\beta_{A T T}=E\left[\left(y_{i t}-y_{i, t-p}\right) \mid \rho, D=1\right]-E\left[\left(y_{i t}-y_{i, t-p}\right) \mid \rho, D=0\right]
$$

where $y_{i t}$ and $y_{i t-p}$ denote labour productivity (alternatively number of workers or total sales) of firm $i$ in years $t$ and $t-p$ and with $0<\mathrm{p}<3$. According to this hypothesis, starting to export early increases productivity, since exporting firms could benefit from technological feedback 
provided by international clients and competitors. An increase in exporters' post-entry performance is expected.

\subsection{Data description}

The two datasets used in this paper are from the World Bank Enterprise Surveys. The interviews were conducted in 2004 and 2006-2007 and contain 2,316 observations for Egyptian firms and 1539 for Moroccan firms (Table 1). The firms surveyed are mainly manufacturers; services were included in the Egyptian surveys for both years, but in 2007 in the case of the Moroccan survey.

\section{Table 1. Survey Summaries}

As shown in Table 1, 24 percent out of all firms surveyed in Egypt in 2004 are exporters (60 percent in Morocco) and this percentage increases to 31 percent in 2007 for Egypt, whereas it decreases to 37 percent in Morocco. It is worth noting that these percentages vary widely depending on the type of activity, as can be seen in Figures 1 and 2, where the percentage of exporter firms over total firms surveyed is shown per each sector and year in Egypt and Morocco, respectively. The sector-by-sector disaggregation is more detailed in the Egyptian survey, which includes 18 industries, whereas in the Moroccan survey firms are only classified into 7 types of activities. Figure 1 shows that the most important exporting industries in Egypt are vegetables and fruits, metals fertilizers and fuels. The percentage of firms exporting has grown substantially in most sectors, especially motor vehicles and electrical appliances.

\section{Figure 1. Percentage of exporting firms by sector in Egypt}

The number of exporters in Morocco has only risen in the clothing sector. Furthermore, 20 percent of firms became exporters in the machinery and equipment sector. The percentage of 
exporting firms remained stable in electronics (around 50 percent) and in chemical products (around 24 percent), whereas it decreased in food, textiles and other industries.

\section{Figure 2. Percentage of exporting firms by sector in Morocco}

Each survey gathered information about exporting status, total sales and the number of workers for several years, as can be seen in Table 3, which presents the summary statistics. Other characteristics of the firms, namely capital stock and importing activities, are only available for one or two periods. The Egyptian survey provides more detailed information than the Moroccan survey in two aspects. First of all, exporting status is available for four years, whereas it is only given for two years in Morocco. Secondly, there are variables that cannot be obtained from the Moroccan questionnaire, such as the value of intermediate products used in production and capital stock are only available for 2005 . These limitations are important for the empirical application. Indeed, for Morocco we are only able to use sales per employee, sales and number of workers as outcome variables, whereas for Egypt we are also able to estimate a production function to obtain total factor productivity as an alternative measure of labour productivity. In addition labour productivity can only be measured as sales per employee in Morocco, but in Egypt it is also measured as value added per employee, since the value of the inputs used in production is also available for several years.

The series in monetary terms (e.g. sales, capital stock and materials) are deflated using production price indices obtained from the respective country statistics (data sources are shown in Table A.1 in the Appendix).

Table 2. Descriptive statistics for exporters and non-exporters (Egypt, Morocco)

Table 3 shows mean values and standard deviations for the dependent and independent variables used in the empirical analysis. The first half of the table shows statistics for Egypt and the second for Morocco. The evidence is as expected in Egypt: exporters (treated firms) 
are on average more productive and are larger in size in terms of turnover and number of employees than non-exporters. However, the second half of the table reveals a striking fact: Moroccan exporters seems to be on average less productive (have lower sales per employee) than non exporters and this is true for both years of available data, namely 2002 and 2005 . However, Moroccan exporters are larger than non-exporters in terms of number of employees and average sales.

\section{Main Results}

Table 3 presents the results for the export premium hypothesis for several performance variables, first of all labour productivity (M1), number of workers (M2) and sales per employee (M3), which are available for Egypt and Morocco, and secondly for labour productivity in terms of value added per employee (M4) and for total factor productivity (M5), which are only available for Egypt. The results of the differences-in-differences matching estimation indicate that exporting firms are more productive in terms of sales per employee, employ more workers and have a higher turnover than non-exporter firms in Egypt. However, we did not find significant differences between exporters and non-exporters in terms of TFP and value added per employee. In contrast, Moroccan exporters are only different from non-exporters in terms of average number of employees, but do not seem to be more productive and the average treatment effect is also not statistically significant when sales is the performance variable. It is worth noting that this result is not in accordance with the predictions of the Melitz (2003) model or the related theoretical literature.

\section{Table 3. Export premium in Egypt and Morocco, matched sample}

Table 4 shows the results obtained when the self-selection hypothesis is tested (equation (2) above). Outcomes in the first part of the Table indicate that Egyptian manufacturing firms that perform better are more likely to become exporters. In other words, exporters self select into exporting because they perform better than non-exporters. That is, they display higher average 
productivity and size. In this particular case, it does not matter how productivity is measured (sales per employee -column 1-, value-added per employee -column 4- or TFP -column5), the coefficient of the exporter status variable (XD) is always statistically significant and has a positive sign, indicating that exporters are on average almost 70 percent more productive (in terms of value-added per employee) than non exporters even before they start to export. This is not the case for Moroccan firms, for which no differences are found between exporters and non-exporters in terms of average productivity, sales or number of employees.

\section{Table 4. Self-selection in Egypt and Morocco, matched sample}

Finally, Table 5 shows the outcome for the learning-by-doing hypothesis (Equation (3)). The only measure available for productivity is now sales per employee for both countries since the dependent variable is productivity growth and capital stock and materials were not available for the initial years in the Egyptian survey. The results in the first part of the table (Egypt) indicate that productivity growth is positively related both to exporting status in the initial year (when the difference is taken over two or three years, but not for a single year) and also importing status. In contrast, the second part of the table shows that Moroccan firms do not learn by exporting/importing. We also tried similar estimations that did not include initial productivity and the results were similar.

\section{Table 5. Learning by exporting in Egypt and Morocco, matched sample}

Tables A.2 to A.4 in the Appendix show similar results for the full sample of firms (without applying the differences-in-differences matching procedure) and indicate similar outcomes in terms of statistical significance, the main difference being that the magnitude of the estimated effect is considerably larger than those shown above, indicating a considerable estimation bias that justifies the methodology used above to obtain unbiased results. 
Summarizing, the findings differ significantly between Morocco and Egypt, mainly indicating that exporting and also importing is positively correlated to labour productivity and in some cases with TFP for Egyptian firms, but not for Moroccan firms, which do not seem to select into exporting and do not appear to learn by exporting.

\section{Conclusions}

This paper contributes to the recent empirical literature on firm heterogeneity, international trade and firm performance. Using two datasets for Egypt and Morocco in the periods 2004 and 2007, we apply matching and differences-in-differences techniques to test the hypotheses of export premium, self-selection into exporting and learning by doing. The analysis in this paper supports the self-selection hypothesis for Egyptian firms, but not for Moroccan firms and does not provide conclusive evidence that exporting leads to an improvement in productivity in the case of Morocco. Indeed, by matching exporting firms to similar nonexporting firms and using the differences-in-differences method on the matched pairs, it is found that productivity improvements are not always related to export firms.

The outcomes are very different for Morocco and Egypt, mainly indicating that exporting and also importing is positively correlated to labour productivity and in some cases to TFP for Egyptian firms, but not for Moroccan firms, which do not seem to select into exporting or learn by exporting. These surprising results deserve further investigation aimed at ascertaining why the reason behind the different outcome obtained for Morocco, not only with respect to Egypt, but also with respect to most of the previous literature on the relationship between productivity and exporting status using micro-data. Why do the Moroccan results differ? A possible explanation is that the proportion of exporters in the initial year (2002) of the sample is much higher than for other firm-level datasets and those exporters already compete with firms engaged in international trade. Hence, the differences between exporters and non- 
exporters are smaller than in other countries with a smaller proportion of exporting firms. A second reason could be that non-exporter firms tend to be concentrated in industries subject to high transport costs, namely the food industry or industries that generate low value added, like clothing or textiles. 


\section{References}

Atiyas, I. 2010. "Firm-Level Data in the MENA region: Research Questions, Data Requirements and Possibilities" Middle East Development Journal 3 (2), 159-190.

Augier, P., Gasiorek, M., Lovo and Varela, G. 2010. "Paradoxes of Productivity: Trade Liberalization and Morocco" CARIS Working Paper July 2010, Centre for the Analysis of Regional Integration at Sussex, University of Sussex.

Bartelsman, E., and Doms, M. 2000. "Understanding Productivity: Lessons from Longitudinal Micro-Data". Journal of Economic Literature 38 (3): 569-594.

Bernard, Andrew B. and Bradford Jensen, J., 1999. "Exceptional exporter performance: cause, effect, or both?," Journal of International Economics, Elsevier, vol. 47(1), pages 1-25, February.

Bernard, A. Bradford Jensen, J. B., Redding, S. J. and Schott, P. K. 2007. "Firms in International Trade." Journal of Economic Perspectives, 21: 105-130.

Bernard, A. Bradford Jensen, J. B., Redding, S. J. and Schott, P. K. 2011. "The Empirics of Firm Heterogeneity and International Trade," CEP Discussion Papers dp1084, Centre for Economic Performance, LSE.

Clerides, S. K., S. Lach and Tybout, J. R. 1998. "Is Learning by Exporting Important? Microdynamic Evidence from Colombia, Mexico, and Morocco", Quarterly Journal of Economics, 113 (2), 903-47.

Damijan, P. J. and Kostevc, C. 2007. "Learning-by-Exporting: Continuous Productivity Improvements or Capacity Utilization Effects? Evidence from Slovenian Firms", Review of World Economics, 142, 3, 599-614.

De Loecker, J. 2007. "Do Exports Generate Higher Productivity? Evidence from Slovenia", Journal of International Economics, 73, 1, 69-98.

Fafchamps, M., Hamine, S. E. and Zeufack, A. 2008. "Learning to Export: Evidence from Moroccan Manufacturing," Journal of African Economies, Oxford University Press, vol. 17(2), pages 305-355.

Greenaway, D. and R. Kneller (2004), 'Exporting and Productivity in the United Kingdom', Oxford Review of Economic Policy, 20, 3, 358-71.

Greenaway, D., Gullstrand, J. and Kneller, R. 2005. "Exporting May Not Always Boost Firm Productivity", Review of World Economics (Weltwirtschaftliches Archiv), Springer, 141(4), 561-582.

Greenaway, D. and Kneller, R. 2007. "Firm heterogeneity, exporting and foreign direct investment.” Economic Journal 117(517): F134-F161.

Heckman, J.J., Ichimura, H. and Todd, P. E. 1997. "Matching As An Econometric Evaluation Estimator: Evidence from Evaluating a Job Training Programme", Review of Economic Studies 64, 605-654.

Leuven, E. and Sianesi, B. 2003. "PSMATCH2: Stata module to perform full Mahalanobis and propensity score matching, common support graphing, and covariate imbalance testing". http://ideas.repec.org/c/boc/bocode/s432001.html.

Martins, P. and Yang, Y. 2009. "The Effects of Exporting on Firm Productivity: A Metaanalysis of the Learning-by-Exporting Hypothesis", Review of World Economics, 145, $3,431-45$. 
Melitz, M. J. 2003. "The Impact of Trade on Intra-Industry Reallocations and Aggregate Industry Productivity." Econometrica, 71(6): 1695-1725.

Pavcnik, N. 2002. "Trade liberalization, exit, and productivity improvement: Evidence from Chilean plants." Review of Economic Studies, 69(1): 245-276.

Rosenbaum, P.R. and Rubin, D.B. 1983. "The Central Role of the Propensity Score in Observational Studies for Causal Effects", Biometrika 70, 1, 41-55.

Sekkat, K. (ed.) 2010. Market Dynamics and Productivity in Developing Countries, Springer and International Development Research Center. New York. E-book available at http://idl-bnc.idrc.ca/dspace/bitstream/10625/41135/1/129082.pdf.

Tybout, J. 2000. "Manufacturing firms in developing countries: How well do they do, and why?" Journal of Economic Literature, 38(1), 11-44.

Wagner, J. 2002. "The Causal Effect of Exports on Firm Size and Labour Productivity: First Evidence from a Matching Approach”, Economics Letters, 77, 2, 287-92.

Wagner, J. 2007. "Exports and Productivity: A Survey of the Evidence from Firm-Level Data." The World Economy, 30(1), 60-82.

Yang, Y. and S. Mallick. 2010. "Export premium, self-selection and learning-by-exporting:

Evidence from Chinese matched firms.” The World Economy, 33(10), 1201-1213. 


\section{FIGURES}

Figure 1. Percentage of exporting firms by sector in Egypt

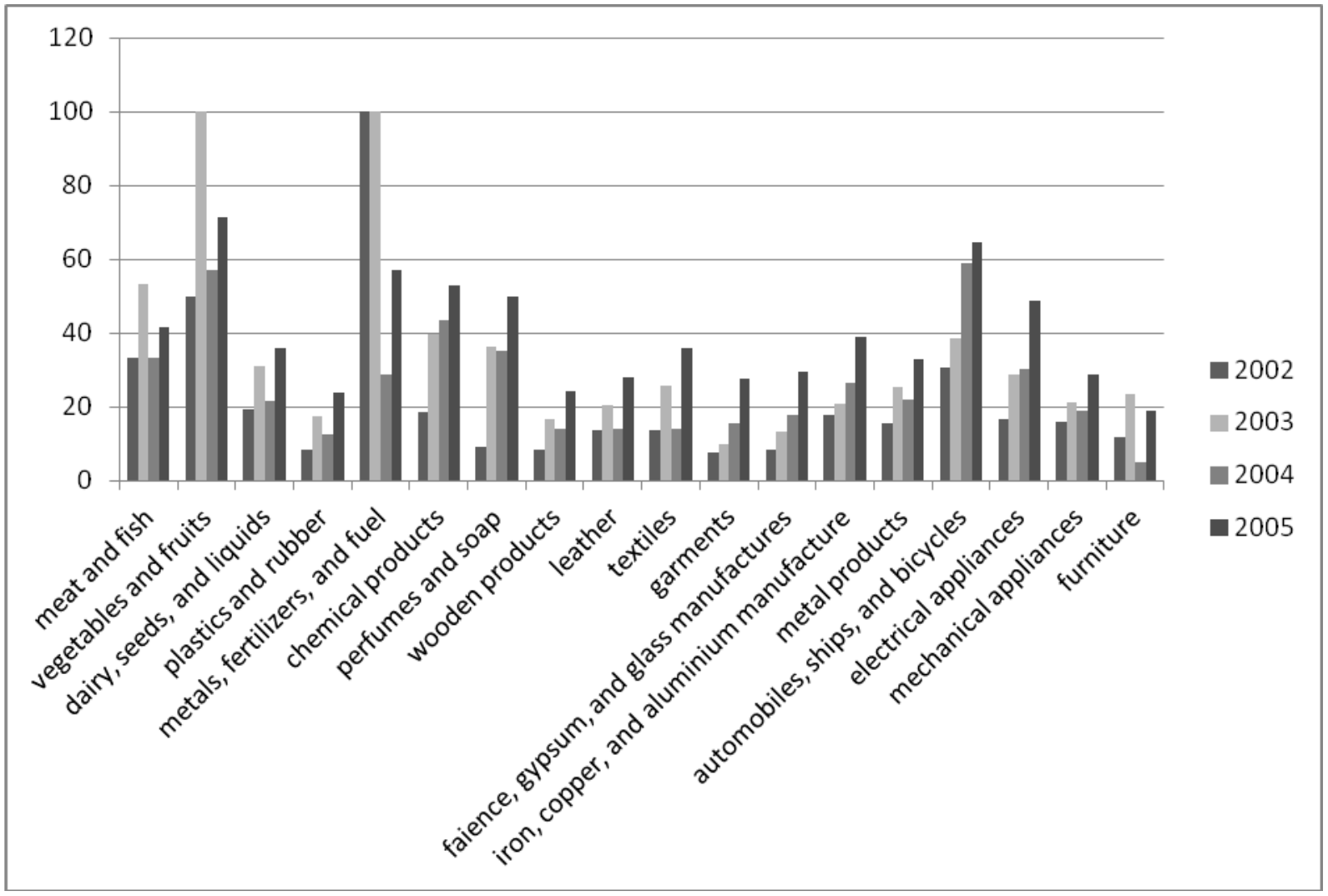


Figure 2. Percentage of exporting firms by sector in Morocco

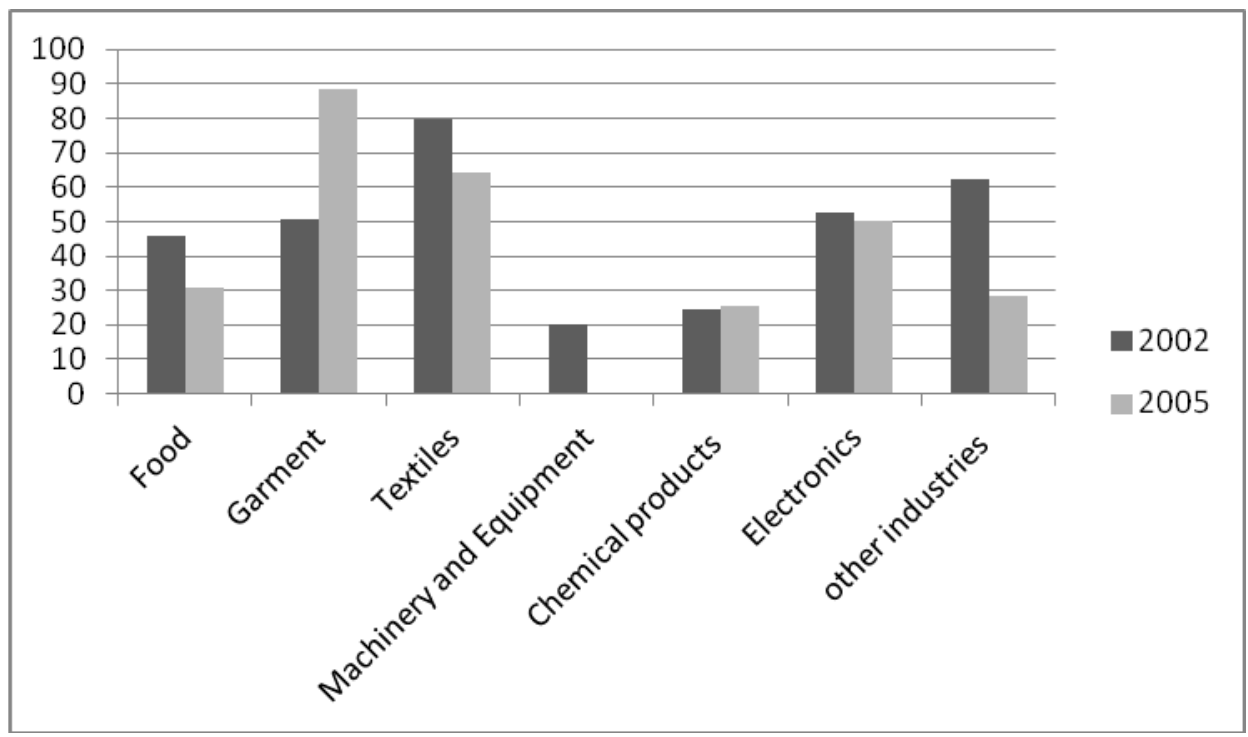




\section{TABLES}

Table 1 Survey Summaries

\begin{tabular}{lcccc}
\hline Number of Firms & $\mathbf{2 0 0 4}$ & $\mathbf{2 0 0 7}$ & Total obs. & Panel \\
\hline Egypt & 977 & 1339 & 2316 & $695^{*}$ \\
Morocco & 850 & 689 & 1539 & $278^{*}$ \\
\hline Exporting activity all firms surveyed & & & \\
\hline Year Survey & $\mathbf{2 0 0 4}$ & $\mathbf{2 0 0 7}$ & \\
Egypt & $24 \%$ & $31 \%$ & \\
Morocco & $60 \%$ & $37 \%$ & \\
\hline Note: $*$ number of firms surveyed each year.
\end{tabular}


Table 2. Descriptive statistics for exporters and non-exporters (Egypt, Morocco)

\begin{tabular}{|c|c|c|c|c|c|c|c|}
\hline \multirow{2}{*}{$\frac{\text { EGYPT }}{\text { Variable }}$} & \multicolumn{3}{|c|}{ Untreated } & \multicolumn{4}{|c|}{ Treated } \\
\hline & Obs. & Mean & Std. Dev. & Obs. & Mean & Std. Dev. & t-test \\
\hline TFP_2004 & 1106 & 7575.614 & 51584.67 & 513 & 41890.35 & 96458.23 & 9.31 \\
\hline TFP_2005 & 1259 & 6610.16 & 41120.1 & 552 & 36369.62 & 78240.78 & 10.57 \\
\hline Sales_2004 & 1205 & 8081.589 & 47208.56 & 540 & 100863.9 & 842926.8 & 3.81 \\
\hline Sales_2005 & 1358 & 15804.28 & 147730 & 579 & 100990.4 & $8.61 \mathrm{E}+05$ & 3.53 \\
\hline Labp_2004 & 1205 & 82.603614 & 120.15025 & 540 & 164.33142 & 436.74059 & 2.34 \\
\hline Labp_2005 & 1358 & 166.10261 & 398.24613 & 579 & 189.08664 & 669.82832 & 3.02 \\
\hline labp_va_2004 & 1177 & 158.8151 & 2254.133 & 530 & 542.5858 & $6.29 \mathrm{E}+03$ & 1.85 \\
\hline labp_va_2005 & 1349 & 124.489 & 1744.945 & 571 & 337.7803 & 3509.007 & 1.77 \\
\hline K_2004 & 1186 & 133.3828 & 890.835 & 528 & 778.6787 & 4601.085 & 4.64 \\
\hline K_2005 & 1289 & 32012.83 & 400966.1 & 561 & 96909.68 & 649732.3 & 2.62 \\
\hline Nwork_2004 & 1364 & 97.83578 & 392.9127 & 577 & 613.7834 & 1930.04 & 9.43 \\
\hline Nwork_2005 & 1388 & 95.14769 & 370.9515 & 584 & 534.0959 & 1285.404 & 11.63 \\
\hline Firm age & 913 & 23.39869 & 16.32842 & 423 & 26.13002 & 18.62538 & 2.72 \\
\hline Manufacture & 1662 & 81.49759 & 36.85632 & 654 & 87.26911 & 30.87312 & 3.54 \\
\hline MOROCCO & \multicolumn{3}{|c|}{ Untreated } & \multicolumn{4}{|c|}{ Treated } \\
\hline Variable & Obs. & Mean & Std. Dev. & Obs. & Mean & Std. Dev. & t-test \\
\hline Sales_2002 & 731 & $7.60 \mathrm{E}+07$ & $3.42 \mathrm{E}+08$ & 715 & $8.82 \mathrm{E}+07$ & $8.31 \mathrm{E}+08$ & 0.16 \\
\hline Sales_2005 & 742 & $2.53 \mathrm{E}+08$ & $4.45 \mathrm{E}+09$ & 758 & $8.36 \mathrm{E}+07$ & $6.21 \mathrm{E}+08$ & -1.03 \\
\hline Labp_2002 & 715 & 697707.9 & 1735325 & 691 & 374621.9 & 1439013 & -3.91 \\
\hline Labp_2005 & 581 & $1.10 \mathrm{E}+07$ & $2.51 \mathrm{E}+08$ & 726 & 304351.8 & 656552.1 & -1.15 \\
\hline K_2005 & 582 & 6851607 & $2.55 \mathrm{E}+07$ & 728 & $1.46 \mathrm{E}+07$ & $7.19 \mathrm{E}+07$ & 2.47 \\
\hline Nwork_2002 & 723 & 65.32365 & 131.0662 & 700 & 183.9214 & 307.6868 & 9.51 \\
\hline Nwork_2005 & 586 & 61.30205 & 197.269 & 729 & 194.2442 & 268.5951 & 10.01 \\
\hline age & 748 & 23.84091 & 17.04416 & 761 & 17.94481 & 12.86661 & -7.59 \\
\hline
\end{tabular}

Notes: Descriptive statistics based on the World Bank investment climate (WBIC) surveys 2004 and 2007. 'TFP=total factor productivity, 'Sales', 'labp_va=Value Added per Worker' and ' $\mathrm{K}=$ Capital' are in Egyptian (Moroccan) currency. 'Treated Group' refers to the group of exporters. 'Control Group' refers to the group of non-exporters. 'Sales' is the annual turnover of the firm. 'Labp=Sales per Worker' is the average sales per worker per year. ' $\mathrm{K}=$ Capital' contains the value of buildings, production machinery and equipment excluding IT, cars, vans and trucks. 'Nwork" denotes the annual employment of the firm. 'Firm Age' refers to the number of years since the firm was established. 'Manufacture' is a dummy equal to one if the firm is a manufacturer. ' $t$ Test' is the mean comparison test of firm characteristics between exporters and non-exporters. 
Table 3. Export premium in Egypt and Morocco, matched sample

\begin{tabular}{|c|c|c|c|c|c|}
\hline EGYPT & Lnlabp_2005 & Lnwork_2005 & Lsales_2005 & Inlabp_va_2005 & Ltfp_2005 \\
\hline Dep Var & M1 & M2 & M3 & M4 & M5 \\
\hline \multirow[t]{2}{*}{ XD } & $0.302 *$ & $0.342 * *$ & $0.302 *$ & 0.282 & 0.165 \\
\hline & 0.171 & 0.134 & 0.171 & 0.185 & 0.117 \\
\hline \multirow[t]{2}{*}{ Lk_2005 } & $0.372 * * *$ & $0.273 * * *$ & $0.372 * * *$ & $0.357 * * *$ & $0.327 * * *$ \\
\hline & 0.083 & 0.046 & 0.083 & 0.089 & 0.05 \\
\hline \multirow[t]{2}{*}{ Lskill_2005 } & 0.111 & $-0.164 *$ & 0.111 & 0.153 & 0.006 \\
\hline & 0.152 & 0.097 & 0.152 & 0.158 & 0.102 \\
\hline \multirow[t]{2}{*}{ Lnwork_2005 } & $-0.355 * * *$ & & $0.645 * * *$ & $-0.365 * * *$ & $0.689 * * *$ \\
\hline & 0.097 & & 0.097 & 0.102 & 0.065 \\
\hline \multirow[t]{2}{*}{ Cons } & $2.823 * *$ & $1.420 * * *$ & $2.823 * *$ & 2.118 & $2.295 * * *$ \\
\hline & 1.305 & 0.504 & 1.305 & 1.53 & 0.481 \\
\hline Nobs & 392 & 402 & 392 & 370 & 393 \\
\hline $\mathbf{R} 2$ & 0.32 & 0.42 & 0.59 & 0.28 & 0.75 \\
\hline AIC & 1479.47 & 1297.50 & 1479.47 & 1429.19 & 1165.88 \\
\hline BIC & 1622.44 & 1437.38 & 1622.44 & 1570.08 & 1308.93 \\
\hline RMSE & 1.53 & 1.17 & 1.53 & 1.59 & 1.02 \\
\hline \multirow[t]{2}{*}{ MOROCCO } & Lnlabp_2005 & Lnwork_2005 & Lsales_2005 & & \\
\hline & M1 & M2 & M3 & & \\
\hline \multirow[t]{2}{*}{ XD } & 0.138 & $0.315 * * *$ & 0.138 & & \\
\hline & 0.139 & 0.1 & 0.139 & & \\
\hline \multirow[t]{2}{*}{ Lk_2005 } & $0.289 * * *$ & $0.279 * * *$ & $0.289 * * *$ & & \\
\hline & 0.04 & 0.031 & 0.04 & & \\
\hline \multirow[t]{2}{*}{ Skill_2005 } & 0.121 & $0.260 * * *$ & 0.121 & & \\
\hline & 0.123 & 0.088 & 0.123 & & \\
\hline \multirow[t]{2}{*}{ Lnwork_2005 } & $-0.283 * * *$ & & $0.717 * * *$ & & \\
\hline & 0.065 & & 0.065 & & \\
\hline \multirow[t]{2}{*}{ Cons } & $9.123 * * *$ & $0.822 *$ & $9.123 * * *$ & & \\
\hline & 0.531 & 0.459 & 0.531 & & \\
\hline Nobs & 319 & 319 & 319 & & \\
\hline $\mathbf{R} 2$ & 0.44 & 0.36 & 0.64 & & \\
\hline AIC & 908.38 & 781.66 & 908.38 & & \\
\hline BIC & 957.33 & 826.85 & 957.33 & & \\
\hline RMSE & 0.99 & 0.81 & 0.99 & & \\
\hline
\end{tabular}

Note: XD is a dummy that takes a value of one if a firm is exporting in a given year. L before a variable name denotes natural logarithms; $\mathrm{k}$ denotes capital stock and nwork the number of workers. All regressions include time, sector and regional dummies. Robust standard errors clustered by sector are reported below each coefficient. $* \mathrm{p}<0.10, * * \mathrm{p}<0.05, * * * \mathrm{p}<0.01$. 
Table 4. Self-selection in Egypt and Morocco, matched sample

\begin{tabular}{|c|c|c|c|c|c|}
\hline EGYPT & Lnlabp_2004 & Lnwork_2004 & Lsales_2004 & Inlabp_va_2004 & Ltfp_2004 \\
\hline Dep Var & M1 & M2 & M3 & M4 & M5 \\
\hline \multirow[t]{2}{*}{ XD } & $0.516 * * *$ & $0.531 * * *$ & $0.516 * * *$ & $0.517 * * *$ & 0.106 \\
\hline & 0.161 & 0.145 & 0.161 & 0.162 & 0.118 \\
\hline \multirow[t]{2}{*}{ Lnwork_2004 } & -0.081 & & $0.919 * * *$ & -0.077 & $0.954 * * *$ \\
\hline & 0.065 & & 0.065 & 0.067 & 0.051 \\
\hline \multirow[t]{2}{*}{ Cons } & $7.601 * * *$ & $3.295 * * *$ & $7.601 * * *$ & $7.586 * * *$ & $8.050 * * *$ \\
\hline & 0.648 & 0.659 & 0.648 & 0.649 & 0.461 \\
\hline Nobs & 359 & 398 & 359 & 357 & 351 \\
\hline $\mathbf{R} 2$ & 0.24 & 0.28 & 0.60 & 0.24 & 0.73 \\
\hline Aic & 1318.21 & 1388.21 & 1318.21 & 1313.59 & 1059.02 \\
\hline Bic & 1446.36 & 1519.76 & 1446.36 & 1441.56 & 1186.42 \\
\hline Rmse & 1.46 & 1.33 & 1.46 & 1.46 & 1.05 \\
\hline \multirow[t]{2}{*}{ MOROCCO } & Lnlabp_2002 & Lnwork_2002 & Lsales_2002 & & \\
\hline & M1 & M2 & M3 & & \\
\hline \multirow[t]{2}{*}{ XD } & -0.01 & $0.550 * * *$ & -0.01 & & \\
\hline & 0.156 & 0.12 & 0.156 & & \\
\hline \multirow[t]{2}{*}{ Lnwork_2002 } & 0.028 & & $1.028 * * *$ & & \\
\hline & 0.072 & & 0.072 & & \\
\hline \multirow[t]{2}{*}{ Cons } & $12.109 * * *$ & $5.379 * * *$ & $12.109 * * *$ & & \\
\hline & 0.426 & 0.175 & 0.426 & & \\
\hline Nobs & 290 & 295 & 290 & & \\
\hline $\mathbf{R} 2$ & 0.35 & 0.12 & 0.55 & & \\
\hline Aic & 885.90 & 811.07 & 885.90 & & \\
\hline Bic & 926.27 & 847.94 & 926.27 & & \\
\hline Rmse & 1.10 & 0.94 & 1.10 & & \\
\hline
\end{tabular}

Note: XD is a dummy that takes a value of one if a firm is exporting in a given year. L before a variable name denotes natural logarithms, labp denotes sales per employee, labp_va denotes value added per employee tfp denotes total factor productivity, and nwork the number of workers. All regressions include time, sector and regional dummies. Robust standard errors clustered by sector are reported below each coefficient. $* \mathrm{p}<0.10, * *$ $\mathrm{p}<0.05, * * * \mathrm{p}<0.01$. 
Table 5. Learning by exporting in Egypt and Morocco, matched sample

\begin{tabular}{|c|c|c|c|}
\hline SALES/WORKER & Dlabprod_1year & Dlabprod_2years & Dlabprod_2years \\
\hline & M1 & M2 & M3 \\
\hline \multirow{2}{*}{ XD } & -0.102 & $0.289 *$ & \\
\hline & 0.107 & 0.164 & \\
\hline \multirow[t]{2}{*}{ MD } & & & $0.425^{*}$ \\
\hline & & & 0.229 \\
\hline \multirow[t]{2}{*}{ Lnlabp_2004 } & $-0.098 * * *$ & & \\
\hline & 0.037 & & \\
\hline \multirow[t]{2}{*}{ Lnwork_2004 } & -0.037 & & \\
\hline & 0.055 & & \\
\hline \multirow[t]{2}{*}{ Lnlabp_2003 } & & $-0.623^{* * *}$ & $-0.631 * * *$ \\
\hline & & 0.06 & 0.063 \\
\hline \multirow[t]{2}{*}{ Lnwork_2003 } & & -0.014 & -0.056 \\
\hline & & 0.063 & 0.071 \\
\hline \multirow[t]{2}{*}{ Cons } & $-2.653 * *$ & 0.161 & 0.004 \\
\hline & 1.225 & 0.536 & 0.551 \\
\hline Nobs & 356 & 331 & 331 \\
\hline $\mathbf{R 2}$ & 0.08 & 0.51 & 0.51 \\
\hline Aic & $1,077.32$ & $1,241.59$ & $1,239.32$ \\
\hline Bic & $1,209.07$ & $1,374.67$ & $1,372.40$ \\
\hline Rmse & 1.05 & 1.50 & 1.50 \\
\hline \multirow[t]{2}{*}{ Morocco } & Dlabprod_3years & Dlabprod_3years & Dlabprod_3years \\
\hline & M1 & M2 & M3 \\
\hline \multirow[t]{2}{*}{ XD_02 } & 0.012 & 0.028 & \\
\hline & 0.092 & 0.089 & \\
\hline \multirow[t]{2}{*}{ Lnlabp_2002 } & & $-0.435^{* * *}$ & $-0.438 * * *$ \\
\hline & & 0.094 & 0.094 \\
\hline \multirow[t]{2}{*}{ Lnwork_2002 } & & 0.058 & 0.044 \\
\hline & & 0.049 & 0.05 \\
\hline \multirow[t]{2}{*}{ Md } & & & 0.149 \\
\hline & & & 0.092 \\
\hline \multirow[t]{2}{*}{ Cons } & $-0.232 *$ & $4.760 * * *$ & $4.808^{* * *}$ \\
\hline & 0.139 & 1.109 & 1.107 \\
\hline Nobs & 290 & 290 & 290 \\
\hline $\mathbf{R 2}$ & 0.04 & 0.27 & 0.28 \\
\hline Aic & 816.08 & 739.90 & 738.62 \\
\hline Bic & 852.78 & 783.94 & 782.66 \\
\hline Rmse & 0.97 & 0.85 & 0.85 \\
\hline
\end{tabular}

Note: XD is a dummy that takes a value of one if a firm is exporting in a given year. L before a variable name denotes natural logarithms, D denotes first differences, labp denotes labour productivity and nwork the number of workers. All regressions include time, sector and regional dummies. Robust standard errors clustered by sector are reported below each coefficient. $* \mathrm{p}<0.10,{ }^{* *} \mathrm{p}<0.05, * * * \mathrm{p}<0.01$. 
APPENDIX

Table A1. List of variables and sources

\begin{tabular}{|c|c|c|c|}
\hline Variable & Description & Units & Source \\
\hline Sales & Total sales & National currency & WBES \\
\hline $\begin{array}{l}\text { Number of } \\
\text { workers }\end{array}$ & Total number of workers & Count & WBES \\
\hline Exporting status & $\begin{array}{l}\text { Takes a value of } 1 \text { if a firm is } \\
\text { exporting in a given year }\end{array}$ & NA & WBES \\
\hline Importing status & $\begin{array}{l}\text { Takes a value of } 1 \text { if a firm is } \\
\text { importing in a given year }\end{array}$ & NA & WBES \\
\hline Capital & $\begin{array}{l}\text { Net book value of machinery } \\
\text { and equipment }\end{array}$ & National currency & WBES \\
\hline Skill & $\begin{array}{l}\text { Number of workers with } \\
\text { secondary or tertiary education }\end{array}$ & Count & WBES \\
\hline Labour cost & Total payment to workers & National currency & WBES \\
\hline $\begin{array}{l}\text { Labour } \\
\text { productivity }\end{array}$ & Sales per employee & National currency per worker & WBES \\
\hline $\begin{array}{l}\text { Value of imported } \\
\text { inputs }\end{array}$ & $\begin{array}{l}\text { Total purchases of row } \\
\text { materials }\end{array}$ & National currency & WBES \\
\hline $\begin{array}{l}\text { Total factor } \\
\text { productivity }\end{array}$ & $\begin{array}{l}\text { Estimated values from a } \\
\text { production function }\end{array}$ & National currency & WBES \\
\hline Age of the firm & Years since creation & Years & WBES \\
\hline $\begin{array}{l}\text { Industry Price } \\
\text { Index Egypt }\end{array}$ & $\begin{array}{l}\text { Producer annual price index by } \\
\text { main groups }\end{array}$ & Base year 2005 & $\begin{array}{l}\text { Central Agency for } \\
\text { Public Mobilization and } \\
\text { Statistics. Arab Republic } \\
\text { of Egypt. } \\
\text { http://www.capmas.gov.e } \\
\text { g/ }\end{array}$ \\
\hline $\begin{array}{l}\text { Industry Price } \\
\text { Index Morocco }\end{array}$ & $\begin{array}{l}\text { Producer annual price index by } \\
\text { main groups }\end{array}$ & Base year 2005 & $\begin{array}{l}\text { Haut Commissariat au } \\
\text { Plan, Royaume du } \\
\text { Maroc. } \\
\text { http://www.hcp.ma/ }\end{array}$ \\
\hline
\end{tabular}

Note: WBES denotes World Bank Enterprise Survey. 
Table A2. Export premium in Egypt and Morocco full sample

\begin{tabular}{|l|l|l|l|}
\hline Egypt & M1 (lab_pro) & M2 (Size) & M3 (Sales) \\
\hline DX & $0.593^{* * *}$ & $1.608^{* * *}$ & $2.225^{* * *}$ \\
\hline & 0.086 & 0.071 & 0.109 \\
\hline Nobs & 1932 & 1972 & 1932 \\
\hline R2 & 0.07 & 0.37 & 0.31 \\
\hline Morocco & M1 (lab_pro) & M2 (Size) & M3 (Sales) \\
\hline DX & -0.1 & $1.085^{* * *}$ & $0.891^{* * *}$ \\
\hline & 0.079 & 0.063 & 0.101 \\
\hline Nobs & 1307 & 1315 & 1500 \\
\hline R2 & 0.26 & 0.24 & 0.18 \\
\hline
\end{tabular}

Note: DX is a dummy that takes a value of 1 when a firm is exporting in a given year. Robust standard errors clustered by sector are reported below each coefficient. $* \mathrm{p}<0.10, * * \mathrm{p}<0.05, * * * \mathrm{p}<0.01$ 
Table A3. Self-selection in Egypt and Morocco full sample

\begin{tabular}{|l|l|l|l|}
\hline \multicolumn{5}{|l|}{ Egypt } & \multicolumn{2}{l|}{ M1 (lab_pro) } & M2 (Size) & M3 (Sales) \\
\hline Dep var 2003 & $0.228^{* *}$ & $1.547^{* * *}$ & $1.639^{* * *}$ \\
\hline & 0.105 & 0.075 & 0.11 \\
\hline Nobs & 1607 & 1895 & 1999 \\
\hline R2 & 0.07 & 0.34 & 0.43 \\
\hline Morocco & & & \\
\hline Dep var 2003 & M1 (lab_pro) & M2 (Size) & M3 (Sales) \\
\hline XD_2005 & $-0.180^{* *}$ & $0.946^{* * *}$ & $0.829^{* * *}$ \\
\hline Nobs & 1307 & 1315 & 1500 \\
\hline R2 & 0.33 & 0.21 & 0.18 \\
\hline Note: DX is a & & & \\
\hline
\end{tabular}

Note: DX is a dummy that takes a value of 1 when a firm is exporting in a given year. Robust standard errors clustered by sector are reported below each coefficient. $* \mathrm{p}<0.10, * * \mathrm{p}<0.05, * * * \mathrm{p}<0.01$. 
Table A4. Learning by exporting in Egypt and Morocco full sample

\begin{tabular}{|l|l|l|l|}
\hline Egypt & $\begin{array}{l}\text { Change in } \\
\text { Labour } \\
\text { Productivity } \\
\text { (1 year) }\end{array}$ & $\begin{array}{l}\text { Change in } \\
\text { Labour } \\
\text { Productivity } \\
\text { (2 years) }\end{array}$ & $\begin{array}{l}\text { Change in } \\
\text { Labour } \\
\text { Productivity } \\
\text { (2 years) }\end{array}$ \\
\hline XDP & -0.125 & $0.38 *^{* * *}$ & \\
\hline & 0.078 & 0.035 & $0.490^{* * *}$ \\
\hline MDP & & & 0.047 \\
\hline & & 1590 & 1590 \\
\hline Nobs & 1716 & 0.07 & 0.07 \\
\hline R2 & .023 & $\begin{array}{l}\text { Change In } \\
\text { Labour } \\
\text { Productivity } \\
\text { (2 Years) }\end{array}$ & $\begin{array}{l}\text { Change In } \\
\text { Labour } \\
\text { Productivity } \\
\text { (2 Years) }\end{array}$ \\
\hline Morocco & & 0.053 & \\
\hline XDP & 0.037 & 0.06 \\
\hline & & & 0.024 \\
\hline MDP & 1199 & 1199 \\
\hline & 0.01 & 0.01 \\
\hline Nobs & &
\end{tabular}

Note: DXP (MDP) is a dummy that takes a value of 1 when a firm is exporting (importing) in a previous year (e.g. 1 year lag in column 1, 2 years lag in column 2). Robust standard errors clustered by sector are reported below each coefficient. $* \mathrm{p}<0.10,{ }^{* *} \mathrm{p}<0.05, * * * \mathrm{p}<0.01$. 
Figure A1. Common support for export premium for Egypt 2007

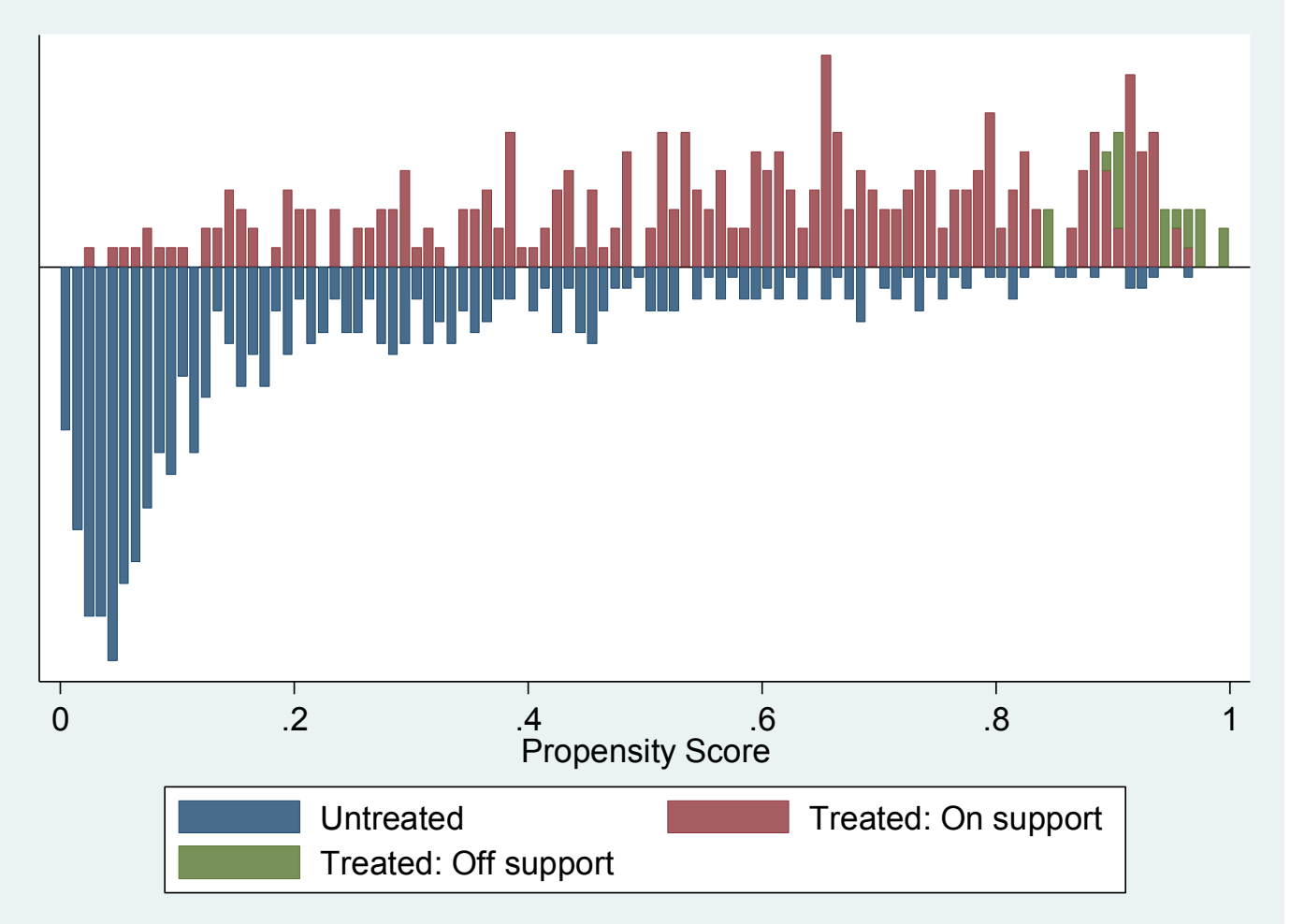


Figure A2. Common support for export premium for Morocco 2007

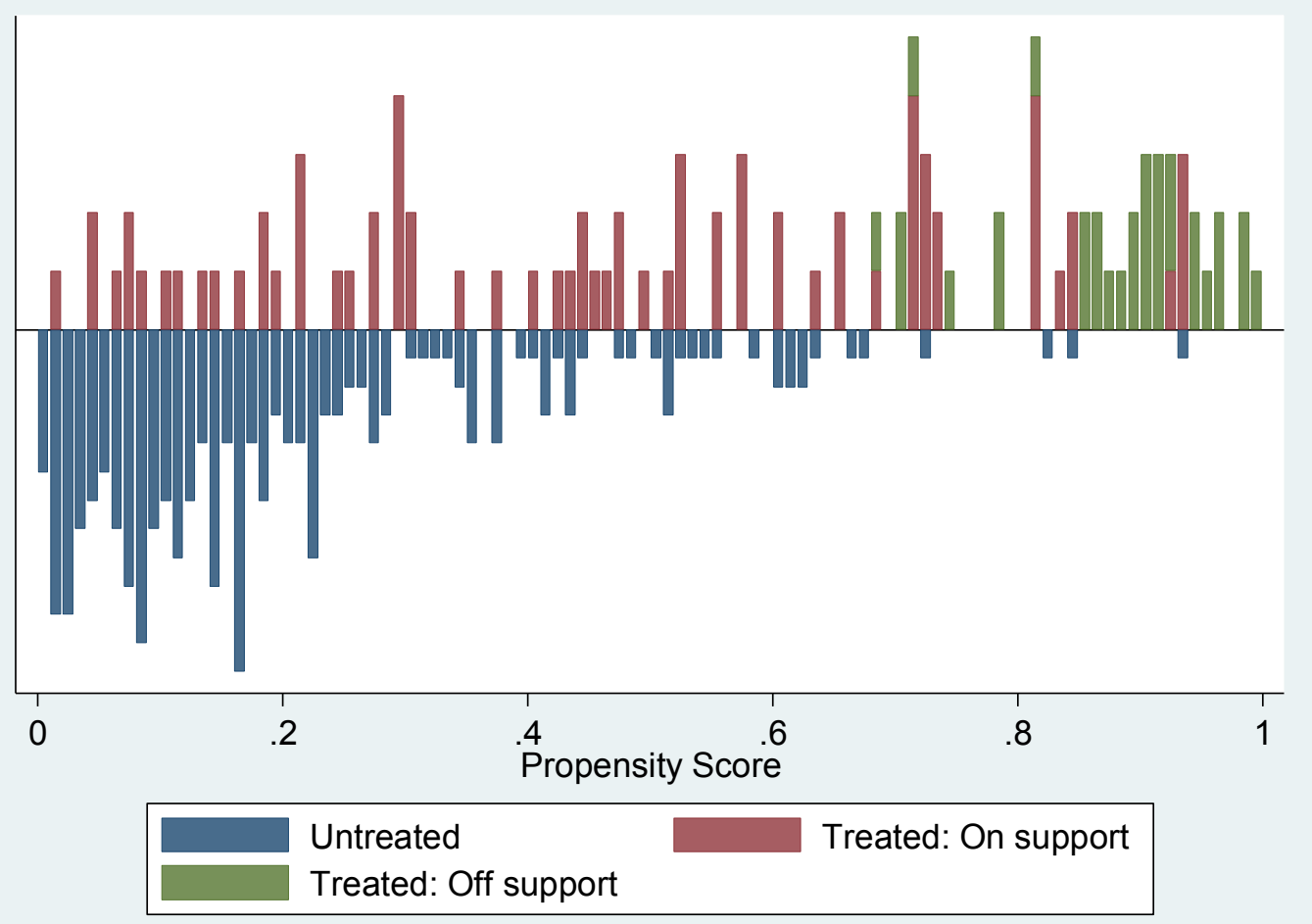

